\title{
Characteristics of Mesenchymal Stem Cells - New Stars in Regenerative Medicine or Unrecognized Old Fellows in Autologous Regeneration?
}

\author{
Richard Schäfer Hinnak Northoff \\ Institute of Clinical and Experimental Transfusion Medicine, University Hospital Tübingen, Germany
}

\section{Key Words}

Mesenchymal stem cells - Marrow stromal cells . Characterization · Differentiation · Regeneration

\section{Summary}

For years mesenchymal stem cells (MSC) have been in the focus of research in the emerging field of regenerative medicine. Due to the heterogeneity of cells with MSClike properties their comprehensive characterization is necessary. In the following, issues of nomenclature, basic characterization, sources, stemness, and therapeutic potential of MSC are discussed, highlighting some aspects in the rapidly expanding field of MSC research.

\section{Introduction}

When Alexander Friedenstein and collegues [1, 2], in the 1970s, described fibroblastoid cells which were obtained from bone marrow (BM) showing colony formation and in vitro as well in vivo osteogenic differentiation potential, it hardly could be predicted that in the following decades the emerging field of stem cell research would focus on cells with similar properties.

Although extensive investigations, from basic stem cell research up to clinical trials, on mesenchymal stem cells / marrow stromal cells (MSC) have been performed by various groups, the knowledge about these cells remains incomplete. The complexity of research on MSC is, among other reasons, based on the fact that numerous subpopulations with more or less MSC-like properties are grouped under the roof of

\section{Schlüsselwörter}

Mesenchymale Stammzellen · Knochenmarkstromazellen · Charakterisierung · Differenzierung · Regeneration

\section{Zusammenfassung}

Seit einigen Jahren befinden sich die mesenchymalen Stammzellen (MSC) im Fokus der Forschung im Bereich der regenerativen Medizin. Aufgrund der Heterogenität der Zellpopulationen, die MSC-artige Eigenschaften aufweisen, ist deren umfangreiche Charakterisierung notwendig. Der folgende Artikel befasst sich mit der Nomenklatur, der grundlegenden Charakterisierung, den Quellen, dem Stammzellcharakter sowie dem therapeutischen Potential der MSC. Hierbei sollen einzelne Aspekte im Bereich der sich rasant entwickelnden MSC-Forschung schlaglichtartig beleuchtet werden.

'MSC'. Therefore, carefully characterizing the cells as MSC which is the initial task before continuing research is time consuming but obligatory.

In the following, the characteristics of MSC which are accepted as essential to date and the possible therapeutic potential of MSC will be discussed. This implies issues of differentiation, paracrine activity and immunomodulation.

\section{Basic Characteristics of Mesenchymal Stem Cells}

Recently some interesting molecules were described which may be useful to identify MSC (sub)populations (CD271, GD2, CD49a, W7C5, W8B2, C15, CDCP1, CD340, CD349, SSEA1/4) [3-7]. However, a distinct exclusively MSC-restricted marker has yet to be identified. Furthermore, the cellular

\begin{tabular}{|c|c|}
\hline KARGER & (C) 2008 S. Karger GmbH, Freiburg \\
\hline $\begin{array}{l}\text { Fax +497614520714 } \\
\text { E-mail Information@Karger.de } \\
\text { www.karger.com }\end{array}$ & $\begin{array}{l}\text { Accessible online at: } \\
\text { www.karger.com/tmh }\end{array}$ \\
\hline
\end{tabular}




\section{The potential of MSC}

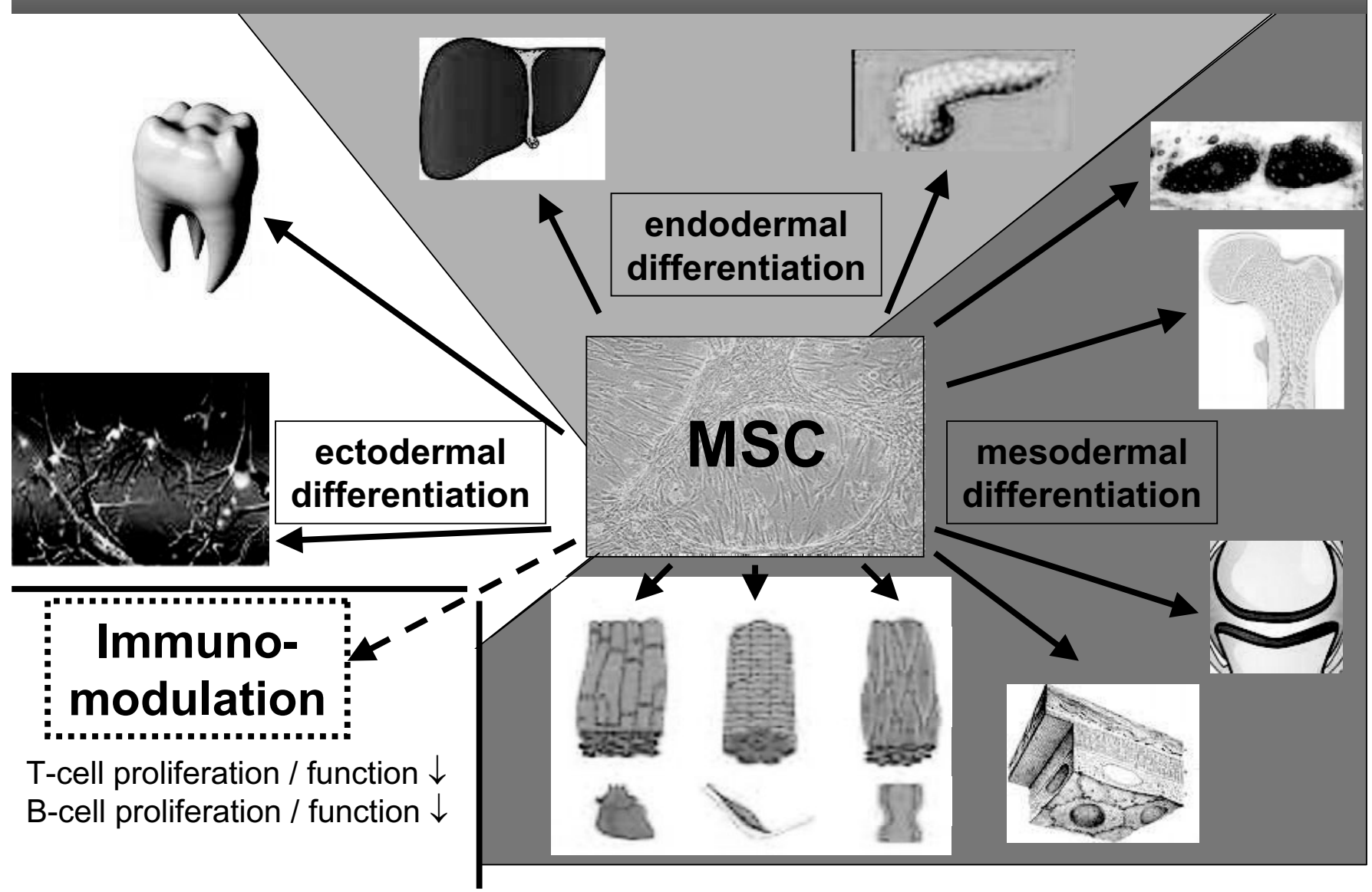

Fig. 1. The differentiation potential (differentiation in cells of mesodermal, endodermal and ectodermal lineage) and immunomodulatory potential of MSC.

shape by itself is not sufficient to determine the cells because the morphology of MSC may vary from spindle shape to broad trapezoid shape depending on culture conditions and passages [8]. Due to the heterogeneity of MSC-like cell populations and biased sample preparations $[9,10]$, it is necessary to standardize the characterization of MSC. For this purpose, a useful approach is application of the minimal criteria for defining MSC which have been published by the International Society for Cellular Therapy (ISCT) [11]. These defining criteria are based on phenotypical and functional issues of cultured MSC:

\section{Surface Antigen Pattern}

Concerning the characterization of the cellular surface, it has to be emphasized that the following antigen pattern is characteristic for human MSC only. MSC isolated from other species, particularly mouse, may show a different pattern which varies among the strains [12]. Moreover, the surface antigen pattern fails to reflect the developmental potential of the MSC [9].
The typical surface antigen pattern of cultured, nonstimulated and/or not differentiated MSC (positive antigen expression is defined $\geq 95 \%$ positive counts, negative antigen expression is defined $\leq 2 \%$ positive counts by flow cytometry) comprises:

- positive antigens: CD73, CD90, CD105,

- negative antigens: CD14 or CD11b, CD34, CD45, CD79 $\alpha$ or CD19, HLA-DR.

\section{Multipotent Differentiation Potential}

Multipotent differentiation is defined as the ability to differentiate into different types of cells/tissue but not to all tissues of the body nor many of the cells that support the pregnancy (pluripotent) or even give rise to a new individual (totipotent) [13]. Cells defined as MSC should show the ability to differentiate into adipogenic, osteogenic and chondrogenic lineage (tri-lineage differentiation potential) after treatment with the respective differentiation media [11].

The in vitro differentiation is usually determined by specific 
staining techniques: MSC in adipogenic differentiation show lipid vacuoles which can be stained with oil red O. Osteogenesis is shown e.g. by staining for alkaline phosphatase and calcium. Glycosaminoglycans in pellets of MSC undergoing chondrogenic differentiation can be stained with toluidine blue [14].

The ISCT definition of MSC requires the ability of plastic adherence. Accounting for reports on nonadherent MSC subpopulations $[15,16]$, plastic adherence may not be an essential aspect of MSC characterization.

It should be pointed out that these issues of characterization are the result of pure in vitro investigations. This implicates that the characterization and comparability of cell populations in respect to their MSC-like properties in vitro is feasible. However, there is evidence that the transferability of the in vitro characteristics into the in vivo situation is limited. The expression of CD45 and CD29 on MSC, for example, is completely different depending on the environment which surrounds the MSC: Freshly isolated MSC express high amounts of CD45 but do not express CD29 on their surface, under culture conditions CD45 is quickly lost, whereas CD29 is up-regulated [17]. Moreover, the antigen expression can be influenced e.g. by stimulation with IFN- $\gamma$ (up-regulation of HLADR) [11] or malignant transformation (loss of CD90) [18]. Antigens that are often detected on human MSC such as CD166 can also be detected on other cell types like malignant melanoma cells [19].

\section{The Nomenclature of Mesenchymal Stem Cells}

Fortunately, the acronym MSC stands for 'mesenchymal stem cells' as well as for 'marrow stromal cells'. At least relating to the BM as source, both terms describe a similar cell population depending on the criteria of definition: Adult 'mesenchymal stem cells' are defined as multipotent cells which can differentiate into mesenchymal and nonmesenchymal lineages. 'Marrow stromal cells', showing a similar differentiation potential, are located in the BM where they interact with hematopoietic stem cells (HSC) supporting them in their niche [14, 20-22]. Other acronyms defining nonhematopoietic stem/progenitor cells with MSC-like properties stand for 'multipotent adult progenitor cells' (MAPC) and 'marrow isolated adult multilineage inducible' (MIAMI) cells [23]. For clarity's sake and because MSC cannot be isolated exclusively from the $\mathrm{BM}$, in the following the acronym 'MSC' is used in general defining 'mesenchymal stem cells'.

\section{Sources of Mesenchymal Stem Cells}

MSC have been isolated from various fetal and postnatal organs and tissues, inlcuding brain, spleen, liver, kidney, lung, muscle, thymus, pancreas, adipose tissue, blood vessels (aorta artery, vena cava, small vessels from kidney glomeruli) and umbilical cord blood $[24,25]$, from various species (humans, rats, mice, cats, dogs, rabbits, pigs, baboons) [8]. Their distribution throughout the organism seems to be related to their prevalence in a perivascular niche [24]. Up to now, it is common assumption that they are usually (i.e. in the absence of pathological status or mobilization procedures [26]) not or only in very low numbers present in adult human peripheral blood [24], but there are reports on isolation of MSC from the peripheral blood of rats [27] and pigs [28]. However, the most common source of MSC is BM. From this compartment, MSC can be isolated in comparatively high numbers and with sufficient differentiation potential. Although a number of different methods has been described for isolating MSC (including antibodyor aptamer-based negative or positive enrichment/depletion techniques and culture-based selection methods [10, 29]) the most frequently applied technique is the selection of MSC by plastic adherence using the affinity of MSC to plastic surfaces [14]. However, with this technique a contamination with other adherent cells without MSC-like properties is unavoidable. The frequency of MSC in the bone marrow is up to $0.01 \%$ of the mononuclear cells after plastic adherence [3, 30, 31]. It has to be pointed out that MSC preparations from different species (human, mouse, rat) and sources (BM, adipose tissue or umbilical cord blood) may vary in their surface epitope pattern, differentiation or proliferation capacity $[12,25,32]$.

\section{Mesenchymal 'Stem' Cells?}

Referring to this question, Javazon et al. [8] pointed out that, due to their proliferative potential, their clonal regeneration and their differentiation potential, MSC may fulfill the current criteria of stem cells (capacity for self-renewal and ability to give rise to one or more types of differentiated progeny). In contrast to embryonic stem cells or tumor cell lines, adult MSC or HSC show senescence in vitro due to the declining activity of telomerase $[8,13,33]$. The subsequent telomere shortening is regarded as a mechanism in long-lived mammals, avoiding unlimited and life-threatening proliferation of organspecific stem cells [13]. It is reasonable to ascribe MSC a kind of 'stemness' in the first place because of their multipotentiality and capacity of transdifferentiation [34]. According to the morphological and phenotypical hetereogeneity of MSC, there is a functional heterogeneity among MSC. MSC populations of different donors for example vary in their growth properties and osteogenic differentiation potential $[35,36]$. Moreover, the tri-lineage differentiation potential could only be ascribed to a minority of clonal MSC preparations [37], and culturing of MSC leads to a loss of multi-potentiality [38]. Beyond the tri-lineage mesodermal differentiation, MSC can in vitro and in vivo transdifferentiate into cells which show phenotypical and functional properties of the neuroectodermal lineage like astrocytes or neurons $[39,40]$. However these 
transdifferentiated MSC cannot be regarded e.g. as neurons because they lack of the neuron-typical properties such as formation of functional filaments or adequate electrophysiological behavior [7]. More in vitro and in vivo experiments demonstrate the broad plasticity of MSC: There are numerous reports on differentiation of MSC into cells with myogenic or cardiomyogenic properties in vitro [41, 42]. After transplantation, MSC had been shown to differentiate in vivo into various epithelial cell types, e.g. pneumocytes, myofibroblasts, retinal pigment epithelial cells, skin epithelial cells, sebaceous duct cells as well as renal tubular epithelial cells [7].

\section{Regeneration by Mesenchymal Stem Cells}

In disease models like myocardial infarction, cerebral ischemic stroke, pulmonary fibrosis, nephropathy and osteogenesis imperfecta systematically administered MSC engraft preferentially to the site of injury [14]. These observations and their differentiation potential soon led to the mechanistic assumption that MSC may represent ideal candidates for tissue regeneration. Actually, the application of MSC resulted in significant clinical improvement in various diseases (osteogenesis imperfecta, lung injury, kidney disease, diabetes, myocardial infarction) and neurological disorders (cerebral ischemia) and other diseases of the central nervous system, including neurodegenerative and inflammatory disorders [7, 43-45]. Interestingly, the therapeutic effects of MSC seem not necessarily require the in vivo differentiation of the MSC. Moreover, only a minority of the MSC shows long-term survival after transplantation [46]. Therefore, it is reasonable to assume that a paracrine activity of MSC (e.g. the secretion of growth factors and other cytokines) leads to tissue regeneration [7, 14, 47, 48]. Due to the gap between the low survival and in vivo transdifferentiation rates and the evident clinical effects, the paracrine activity of MSC could possibly be regarded as the more relevant mechanism for tissue repair as compared to transdifferentiation [7]. Referring to autologous regeneration, in all probability MSC act as an internal cellular resource in order to repair damaged tissue. This hypothesis is supported by the following observations: i) MSC of fetal origin can be detected in maternal tissues long time after pregnancy, participating in tissue regeneration [8]; ii) BM-residing MSC can be mobilized after tissue injury - these cells had been shown to participate in the regeneration of myocardial infarction, skeletal muscle damage or cerebral stroke [23].

\section{Immunomodulation by Mesenchymal Stem Cells}

In vivo observations after administration of MSC like improvement of the outcome after allogeneic transplantations by promotion of hematopoietic engraftment and amelioration of graftversus-host disease $[14,49]$ as well as the amelioration of inflam- matory response and improved clinical course in experimental allergic encephalomyelitis [50] are impressive proofs for the immunomodulatory properties of MSC. Usually, immunomodulation by MSC comes as immunosuppression. This is the result of interactions of MSC with T and B cells: T-cell proliferation and function is suppressed, B-cell proliferation, differentiation and chemotaxis is inhibited [14]. Moreover, MSC have been shown to suppress allospecific antibody production in vitro [51]. At the molecular level, immunomodulation by MSC is mediated e.g. by indoleamine 2,3-dioxygenase (IDO) [52]. IDO, induced by IFN- $\gamma$, catalyzes the metabolization of tryptophan. The tryptophan depletion results in inhibiting the growth and function of T cells [53]. Alternatively, immunomodulation by MSC can be mediated by insulin-like growth factor(IGF)-binding proteins [54], prostaglandin E2 [55] or HLA-G [56].

\section{Malignant Transformation of Mesenchymal Stem Cells and Interactions with Tumor Cells - the Other Side of the Coin}

Despite the options of MSC-based therapy for the treatment of diseases and regeneration of the aged organism, some safety aspects have to be addressed:

There are emerging reports, although controversially discussed [33], on malignant transformation of cultured MSC [18, 57]. Therefore, appropriate tools for the surveillance of MSC cultures have to be developed. Due to the immunosuppressive properties of MSC the question came up whether these cells may promote tumor growth in vivo. Actually, there is evidence that MSC, after systemic administration, home to neoplastic tissue [58-60]. Moreover, MSC are involved in tumor growth in vivo and promote metastasis [61-63].

Finally, trying to answer the question whether MSC are the new stars in regenerative medicine or unrecognized old fellows in autologous regeneration, we may return to history again: Julius Friedrich Cohnheim speculated in the 19th century about the role of BM-derived fibroblasts in wound healing [64]. In the following, numerous investigators worked on the possible transformation of peripheral blood-derived monocytes to macrophages and fibroblasts [65]. Recently, Pufe et al. [66] reported on 'new' adult pluripotent cells derived from human peripheral blood monocytes identified as programmable cells of monocytic origin (PCMO). These cells show multilineage potential comparable to that of MSC. To date it is unclear whether these multipotent, monocyte-derived cells belong to the MSC family or not. Moreover, BM-derived MSC, synovial fibroblasts, dermal fibroblasts and lung-derived fibroblasts which are summarized as 'stromal cells' share not only a common cell surface marker phenotype, but they can also be differentiated in vitro and they are able to inhibit the proliferation of peripheral blood mononuclear cells following polyclonal stimuli indicating a comparable immunosuppressive potential [67]. These results indicate that rather extensive- 
ly characterized and assumed to be well-known cells exhibit properties which are up to now accredited to nonhematopoietic stem or progenitor cells. Possibly it depends on the point of view whether MSC represent a distinct entity of progenitors or whether they are multipotent subpopulations of long 'known' cell types like tissue macrophages or fibroblasts.

\section{Acknowledgement}

This work was supported by the German Ministry of Health (BMBF) Proj. Nr. 0313619

\section{References}

1 Friedenstein AJ, Chailakhjan RK, Lalykina KS: The development of fibroblast colonies in monolayer cultures of guinea-pig bone marrow and spleen cells. Cell Tissue Kinet 1970;3(4):393-403.

2 Friedenstein AJ: Precursor cells of mechanocytes. Int Rev Cytol 1976;47:327-359.

$\checkmark 3$ Quirici N, Soligo D, Bossolasco P, Servida F, Lumin C, Deliliers GL: Isolation of bone marrow mesenchymal stem cells by anti-nerve growth factor receptor antibodies. Exp Hematol 2002;30(7): 783-791.

4 Martinez C, Hofmann TJ, Marino R, Dominici M, Horwitz EM: Human bone marrow mesenchymal stromal cells express the neural ganglioside GD2: a novel surface marker for the identification of MSCs. Blood 2007;109(10):4245-4248.

$\checkmark 5$ Giesert C, Marxer A, Sutherland DR, Schuh AC, Kanz L, Buhring HJ: Antibody W7C5 defines a CD109 epitope expressed on CD34+ and CD34hematopoietic and mesenchymal stem cell subsets. Ann N Y Acad Sci 2003;996:227-230.

6 Bühring HJ, Kuci S, Conze T, Rathke G, Bartolovic K, Grunebach F, Scherl-Mostageer M, Brummendorf TH, Schweifer N, Lammers R: CDCP1 identifies a broad spectrum of normal and malignant stem/progenitor cell subsets of hematopoietic and nonhematopoietic origin. Stem Cells 2004;22(3): 334-343.

7 Phinney DG, Prockop DJ: Concise review: mesenchymal stem/multipotent stromal cells: the state of transdifferentiation and modes of tissue repaircurrent views. Stem Cells 2007;25(11):2896-2902.

8 Javazon EH, Beggs KJ, Flake AW: Mesenchymal stem cells: paradoxes of passaging. Exp Hematol 2004;32(5):414-425.

$\checkmark 9$ Phinney DG: Building a consensus regarding the nature and origin of mesenchymal stem cells. J Cell Biochem Suppl 2002;38:7-12.

10 Schäfer R, Dominici M, Muller I, Dazzi F, Bieback K, Godthardt K, Blanc KL, Meisel R, Pochampally R, Richter R, Skutella T, Steinhoff G, Mitterberger M, Wendel H, Wiskirchen J, Handgretinger R, Northoff H: Progress in characterization, preparation and clinical applications of non-hematopoietic stem cells, 29-30 September 2006, Tubingen, Germany. Cytotherapy 2007;9(4):397-405.

11 Dominici M, Le BK, Mueller I, Slaper-Cortenbach I, Marini F, Krause D, Deans R, Keating A, Prockop D, Horwitz E: Minimal criteria for defining multipotent mesenchymal stromal cells. The International Society for Cellular Therapy position statement. Cytotherapy 2006;8(4):315-317.

$\checkmark 12$ Peister A, Mellad JA, Larson BL, Hall BM, Gibson LF, Prockop DJ: Adult stem cells from bone marrow (MSCs) isolated from different strains of inbred mice vary in surface epitopes, rates of proliferation, and differentiation potential. Blood 2004;103 (5):1662-1668.
13 Verfaillie CM, Pera MF, Lansdorp PM: Stem cells: hype and reality. Hematol Am Soc Hematol Educ Program 2002;369-391.

14 Chamberlain G, Fox J, Ashton B, Middleton J: Concise review: mesenchymal stem cells: their phenotype, differentiation capacity, immunological features, and potential for homing. Stem Cells 2007; 25(11):2739-2749.

15 Dominici M, Pritchard C, Garlits JE, Hofmann TJ, Persons DA, Horwitz EM: Hematopoietic cells and osteoblasts are derived from a common marrow progenitor after bone marrow transplantation. Proc Natl Acad Sci U S A 2004;101(32):11761-11766.

16 Baksh D, Zandstra PW, Davies JE: A non-contact suspension culture approach to the culture of osteogenic cells derived from a CD49e(low) subpopulation of human bone marrow-derived cells. Biotechnol Bioeng 2007;98(6):1195-1208.

17 Guo KT, Schäfer R, Paul A, Gerber A, Ziemer G, Wendel HP: A new technique for the isolation and surface immobilization of mesenchymal stem cells from whole bone marrow using high-specific DNA aptamers. Stem Cells 2006;24(10):2220-2231.

18 Miura M, Miura Y, Padilla-Nash HM, Molinolo AA, Fu B, Patel V, Seo BM, Sonoyama W, Zheng JJ, Baker CC, Chen W, Ried T, Shi S: Accumulated chromosomal instability in murine bone marrow mesenchymal stem cells leads to malignant transformation. Stem Cells 2006;24(4):1095-1103.

19 Klein WM, Wu BP, Zhao S, Wu H, Klein-Szanto AJ, Tahan SR: Increased expression of stem cell markers in malignant melanoma. Mod Pathol 2007;20 (1):102-107.

20 Baksh D, Davies JE, Zandstra PW: Soluble factor cross-talk between human bone marrow-derived hematopoietic and mesenchymal cells enhances in vitro CFU-F and CFU-O growth and reveals heterogeneity in the mesenchymal progenitor cell compartment. Blood 2005;106(9):3012-3019.

21 Dorshkind K, Johnson A, Collins L, Keller GM, Phillips RA: Generation of purified stromal cell cultures that support lymphoid and myeloid precursors. J Immunol Methods 1986;89(1):37-47.

22 Johnson A, Dorshkind K: Stromal cells in myeloid and lymphoid long-term bone marrow cultures can support multiple hemopoietic lineages and modulate their production of hemopoietic growth factors. Blood 1986;68(6):1348-1354.

23 Ratajczak MZ, Zuba-Surma EK, Machalinski B, Kucia M: Bone-marrow-derived stem cells - our key to longevity? J Appl Genet 2007;48(4):307-319.

24 da Silva ML, Chagastelles PC, Nardi NB: Mesenchymal stem cells reside in virtually all post-natal organs and tissues. J Cell Sci 2006;119(Pt 11): 2204-2213.

25 Kern S, Eichler H, Stoeve J, Kluter H, Bieback K: Comparative analysis of mesenchymal stem cells from bone marrow, umbilical cord blood or adipose tissue. Stem Cells 2006;24(5):1294-1301.
26 Ratajczak MZ, Kucia M, Reca R, Majka M, Janowska-Wieczorek A, Ratajczak J: Stem cell plasticity revisited: CXCR4-positive cells expressing mRNA for early muscle, liver and neural cells 'hide out' in the bone marrow. Leukemia 2004;18(1):29-40.

27 Kim S, Honmou O, Kato K, Nonaka T, Houkin K, Hamada H, Kocsis JD: Neural differentiation potential of peripheral blood- and bone-marrow-derived precursor cells. Brain Res 2006;1123(1):27-33.

28 Faast R, Harrison SJ, Beebe LF, McIlfatrick SM, Ashman RJ, Nottle MB: Use of adult mesenchymal stem cells isolated from bone marrow and blood for somatic cell nuclear transfer in pigs. Cloning Stem Cells 2006;8(3):166-173.

29 Guo KT, Schäfer R, Paul A, Ziemer G, Wendel HP: Aptamer-based strategies for stem cell research. Mini Rev Med Chem 2007;7(7):701-705.

30 Pittenger MF, Mackay AM, Beck SC, Jaiswal RK, Douglas R, Mosca JD, Moorman MA, Simonetti DW, Craig S, Marshak DR: Multilineage potential of adult human mesenchymal stem cells. Science 1999;284(5411):143-147.

31 Tondreau T, Lagneaux L, Dejeneffe M, Delforge A, Massy M, Mortier C, Bron D: Isolation of BM mesenchymal stem cells by plastic adhesion or negative selection: phenotype, proliferation kinetics and differentiation potential. Cytotherapy 2004;6(4): 372-379.

32 Schäfer R, Kehlbach R, Wiskirchen J, Bantleon R, Pintaske J, Brehm BR, Gerber A, Wolburg H, Claussen CD, Northoff H: Transferrin receptor upregulation: in vitro labeling of rat mesenchymal stem cells with superparamagnetic iron oxide. Radiology 2007;244(2):514-523.

33 Bernardo ME, Zaffaroni N, Novara F, Cometa AM, Avanzini MA, Moretta A, Montagna D, Maccario R, Villa R, Daidone MG, Zuffardi O, Locatelli F: Human bone marrow derived mesenchymal stem cells do not undergo transformation after long-term in vitro culture and do not exhibit telomere maintenance mechanisms. Cancer Res 2007;67(19): 9142-9149.

34 Song L, Tuan RS: Transdifferentiation potential of human mesenchymal stem cells derived from bone marrow. FASEB J 2004;18(9):980-982.

35 Phinney DG, Kopen G, Righter W, Webster S, Tremain N, Prockop DJ: Donor variation in the growth properties and osteogenic potential of human marrow stromal cells. J Cell Biochem 1999; 75(3):424-436.

36 Kuznetsov SA, Krebsbach PH, Satomura K, Kerr J, Riminucci M, Benayahu D, Robey PG: Singlecolony derived strains of human marrow stromal fibroblasts form bone after transplantation in vivo. $\mathrm{J}$ Bone Miner Res 1997;12(9):1335-1347.

37 Muraglia A, Cancedda R, Quarto R: Clonal mesenchymal progenitors from human bone marrow differentiate in vitro according to a hierarchical model. J Cell Sci 2000;113(Pt 7):1161-1166. 
38 Digirolamo CM, Stokes D, Colter D, Phinney DG, Class R, Prockop DJ: Propagation and senescence of human marrow stromal cells in culture: a simple colony-forming assay identifies samples with the greatest potential to propagate and differentiate. $\mathrm{Br}$ J Haematol 1999;107(2):275-281.

39 Kopen GC, Prockop DJ, Phinney DG: Marrow stromal cells migrate throughout forebrain and cerebellum, and they differentiate into astrocytes after injection into neonatal mouse brains. Proc Natl Acad Sci U S A 1999;96(19):10711-10716.

40 Pacary E, Legros H, Valable S, Duchatelle P, Lecocq M, Petit E, Nicole O, Bernaudin M: Synergistic effects of $\mathrm{CoCl}(2)$ and ROCK inhibition on mesenchymal stem cell differentiation into neuronlike cells. J Cell Sci 2006;119(Pt 13):2667-2678.

41 Wakitani S, Saito T, Caplan AI: Myogenic cells derived from rat bone marrow mesenchymal stem cells exposed to 5-azacytidine. Muscle Nerve 1995; 18(12):1417-1426.

42 Hattan N, Kawaguchi H, Ando K, Kuwabara E, Fujita J, Murata M, Suematsu M, Mori H, Fukuda K Purified cardiomyocytes from bone marrow mesenchymal stem cells produce stable intracardiac grafts in mice. Cardiovasc Res 2005;65(2):334-344.

43 Dezawa M: Insights into autotransplantation: the unexpected discovery of specific induction systems in bone marrow stromal cells. Cell Mol Life Sci 2006;63(23):2764-2772.

44 Uccelli A, Zappia E, Benvenuto F, Frassoni F, Mancardi G: Stem cells in inflammatory demyelinating disorders: a dual role for immunosuppression and neuroprotection. Expert Opin Biol Ther 2006;6(1): 17-22.

45 Honma T, Honmou O, Iihoshi S, Harada K, Houkin $\mathrm{K}$, Hamada H, Kocsis JD: Intravenous infusion of immortalized human mesenchymal stem cells protects against injury in a cerebral ischemia model in adult rat. Exp Neurol 2006;199(1):56-66.

46 Iso Y, Spees JL, Serrano C, Bakondi B, Pochampally R, Song YH, Sobel BE, Delafontaine P, Prockop DJ: Multipotent human stromal cells improve cardiac function after myocardial infarction in mice without long-term engraftment. Biochem Biophys Res Commun 2007;354(3):700-706.

47 Gnecchi M, He H, Noiseux N, Liang OD, Zhang L, Morello F, Mu H, Melo LG, Pratt RE, Ingwall JS Dzau VJ: Evidence supporting paracrine hypothesis for Akt-modified mesenchymal stem cell-mediated cardiac protection and functional improvement. FASEB J 2006;20(6):661-669.
48 Dai Y, Xu M, Wang Y, Pasha Z, Li T, Ashraf M: HIF-1alpha induced-VEGF overexpression in bone marrow stem cells protects cardiomyocytes against ischemia. J Mol Cell Cardiol 2007;42(6):1036-1044

49 Le Blanc K, Rasmusson I, Sundberg B, Gotherstrom C, Hassan M, Uzunel M, Ringden O: Treatment of severe acute graft-versus-host disease with third party haploidentical mesenchymal stem cells. Lancet 2004;363(9419):1439-1441.

50 Zappia E, Casazza S, Pedemonte E, Benvenuto F, Bonanni I, Gerdoni E, Giunti D, Ceravolo A, Cazzanti F, Frassoni F, Mancardi G, Uccelli A: Mesenchymal stem cells ameliorate experimental autoimmune encephalomyelitis inducing T-cell anergy. Blood 2005;106(5):1755-1761.

51 Comoli P, Ginevri F, Maccario R, Avanzini MA, Marconi M, Groff A, Cometa A, Cioni M, Porretti L, Barberi W, Frassoni F, Locatelli F: Human mesenchymal stem cells inhibit antibody production induced in vitro by allostimulation. Nephrol Dial Transplant 2008;23(4):1196-1202.

52 Meisel R, Zibert A, Laryea M, Gobel U, Daubener W, Dilloo D: Human bone marrow stromal cells inhibit allogeneic T-cell responses by indoleamine 2.3-dioxygenase-mediated tryptophan degradation. Blood 2004:103(12):4619-4621.

53 Hwu P, Du MX, Lapointe R, Do M, Taylor MW, Young HA: Indoleamine 2,3-dioxygenase production by human dendritic cells results in the inhibition of T cell proliferation. J Immunol 2000;164(7): 3596-3599.

54 Gieseke F, Schutt B, Viebahn S, Koscielniak E, Friedrich W, Handgretinger R, Muller I: Human multipotent mesenchymal stromal cells inhibit proliferation of PBMCs independently of IFNgammaR1 signaling and IDO expression. Blood 2007; 110(6):2197-2200.

55 Aggarwal S, Pittenger MF: Human mesenchymal stem cells modulate allogeneic immune cell responses. Blood 2005;105(4):1815-1822.

56 Nasef A, Mathieu N, Chapel A, Frick J, Francois S, Mazurier C, Boutarfa A, Bouchet S, Gorin NC, Thierry D, Fouillard L: Immunosuppressive effects of mesenchymal stem cells: involvement of HLA-G. Transplantation 2007;84(2):231-237.

57 Tolar J, Nauta AJ, Osborn MJ, Panoskaltsis MA, McElmurry RT, Bell S, Xia L, Zhou N, Riddle M, Schroeder TM, Westendorf JJ, McIvor RS, Hogendoorn PC, Szuhai K, Oseth L, Hirsch B, Yant SR, Kay MA, Peister A, Prockop DJ, Fibbe WE, Blazar BR: Sarcoma derived from cultured mesenchymal stem cells. Stem Cells 2007;25(2):371-379.
58 Komarova S, Kawakami Y, Stoff-Khalili MA, Curiel DT, Pereboeva L: Mesenchymal progenitor cells as cellular vehicles for delivery of oncolytic adenoviruses. Mol Cancer Ther 2006;5(3):755-766.

59 Dwyer RM, Potter-Beirne SM, Harrington KA, Lowery AJ, Hennessy E, Murphy JM, Barry FP O'Brien T, Kerin MJ: Monocyte chemotactic protein-1 secreted by primary breast tumors stimulates migration of mesenchymal stem cells. Clin Cancer Res 2007;13(17):5020-5027.

60 Studeny M, Marini FC, Dembinski JL, Zompetta C, Cabreira-Hansen M, Bekele BN, Champlin RE, Andreeff M: Mesenchymal stem cells: potential precursors for tumor stroma and targeted-delivery vehicles for anticancer agents. J Natl Cancer Inst 2004;96(21):1593-1603.

61 Karnoub AE, Dash AB, Vo AP, Sullivan A, Brooks MW, Bell GW, Richardson AL, Polyak K, Tubo R, Weinberg RA: Mesenchymal stem cells within tumour stroma promote breast cancer metastasis. Nature 2007:449(7162):557-563.

62 Galie M, Konstantinidou G, Peroni D, Scambi I, Marchini C, Lisi V, Krampera M, Magnani P, Merigo F, Montani M, Boschi F, Marzola P, Orru R, Farace P, Sbarbati A, Amici A: Mesenchymal stem cells share molecular signature with mesenchymal tumor cells and favor early tumor growth in syngeneic mice. Oncogene 2008;27(18):2542-2551.

63 Ramasamy R, Lam EW, Soeiro I, Tisato V, Bonnet D, Dazzi F: Mesenchymal stem cells inhibit proliferation and apoptosis of tumor cells: impact on in vivo tumor growth. Leukemia 2007;21(2):304-310.

64 Prockop DJ: Marrow stromal cells as stem cells for nonhematopoietic tissues. Science 1997;276(5309): 71-74.

65 Krupp S: [Transformation of monocytes into fibroblasts in wound healing (author's transl)]. Res Exp Med (Berl) 1976;167(2):85-126.

66 Pufe T, Petersen W, Fandrich F, Varoga D, Wruck CJ, Mentlein R, Helfenstein A, Hoseas D, Dresse S, Tillmann B, Ruhnke M: Programmable cells of monocytic origin (PCMO): A source of peripheral blood stem cells that generate collagen type II-producing chondrocytes. J Orthop Res 2008;26:(3) 304-313.

67 Jones S, Horwood N, Cope A, Dazzi F: The antiproliferative effect of mesenchymal stem cells is a fundamental property shared by all stromal cells. J Immunol 2007;179(5):2824-2831. 